\title{
The implications for qualitative research methodology of the struggle between the individualised subject of phenomenology and the emergent multiplicities of the poststructuralist the problem of agency
}

\section{Bronwyn Davies}

\section{Melbourne University}

\begin{abstract}
This paper re-visits the problem of how we re-conceptualize human subjects within poststructuralist research. The turn to poststructuralist theory to inform research in the social sciences is complicated by the difficulty in thinking through what it means to put the subjet under erasure. Drawing on a study in a Reggio Emilia inspired preschool in Sweden, and a study of neoliberalism's impact on academic work, this paper opens up thought about poststructuralism's subject. It argues that agency is the province of that subject.
\end{abstract}

This paper is in three parts: first an exploration of the difference between what I am calling phenomenology's subject-of-will, and poststructuralism's subject-of-thought (where the concept of the subject is put under erasure); second an elaboration of the subject-ofthought through two small moments in a Swedish preschool; and third an examination of what has made the subject-of-thought so important for those taking up qualitative research methodologies in the psychological and social sciences, and what it is that this different conceptualising of the subject makes possible in relation to thinking about agency.

In examining the relations between these two concepts I am specifically not creating a binary between individualism and collectivism, or between the subject-of-will and the suject-of-thought. Rather I am interested in the way the hyper-individualism, fostered under neoliberal governmentality, produces lives that are 'nasty and brutish' (to draw on Thomas Hobbes), and reduces the creative impulse that is necessary for creative evolution (Bergson, 1998). The individualised subject under neoliberalism has, in this analysis, reduced agency and reduced capacity to generate new thought. This paper explores what it is that poststructuralist theory has offered qualitative researchers to help re-think human subjectivity and subjectification; it asks how are we to hold together in our thinking the specificity of each subject while understanding the emergence of subjects as co-implicated with others, including non-human others; and how might we maximise human creative evolutionary capacities (Bergson 1998)?

In phenomenological thought the singular, self-contained human individual is fundamental to understanding being. This individual fundamentalism has had a huge impact on Psychology in particular, but more broadly on the Social Sciences and on everyday lives. The individualized subject of phenomenology on whom we have based so much of our thinking about being, is intrinsically, I will argue here, a conservative idea and set of practices. I will call this subject the subject-of-will.

Poststructuralist philosophers have, in common, a decided antagonism to the fundamental 
status given to this individualised subject (Davies et al, 2006). This poses a problem for those psychologists and social scientists interested in poststructuralist theory and in qualitative research in particular. So much of our data comes from the accounts of those very subjects whose sense of their own subject-hood draws, to some extent at least, on the idea of phenomenology's individual. In this paper I will explore how we might think of our research subjects differently, against the grain of phenomenology. I will ask why this different take on the subject matters, and what might be gained by doing this hard work of thinking the subject differently, putting the concept of the under erasure, as poststructuralism invites us to do.

From a poststructuralist perspective the individualised subject-of-will is both an idea and an accomplishment that we each labour over, attempting to make real an idealized image of ourselves - as rational, as responsible-in relation to which we are always judged and found wanting, and against which we judge others and find them wanting (Deleuze, 1980). This primacy of judgement, both of self and other, is based on the assumption that who we are is accomplished through our own choices - 'who we are' is a result of will.

Poststructuralist theory asks, through Foucault's work in particular, how, historically, the conditions of possibility for now one view of what the subject is (and should be), and then another, are formed, and with what effect (see for example the writing of Foucault in Rabinow, 1997a). It asks: How is one kind of subjecthood or another made possible? How does one set of possibilities become normalised such that the subject cannot imagine itself otherwise? And most important, how can the human subject evolve beyond the current sets of actions and reactions? The creative evolution of life depends not on the accomplishment of that idealized image of the subject-of-will, but on openness to the other and the not-yet-known.

Poststructuralist theory suggests that agency, rather than being a product of the individual will, lies in the conditions of possibility that provoke new thought (Badiou, 2000). It is in this sense that I take up the concept of the subject-of-thought, as responsive to those conditions of possibility. One of those conditions, according to Deleuze, is the move from the moralistic judgement made against the imagined ideal, toward an ethics based on immanence, where immanence means to remain within. In a Deleuzian philosophy this does not mean within the bounded self, but within life; not just human life, but all life, organic and inorganic, which Deleuze refers to as Being. It is here that the subject-of-thought is located, not as a bounded self but as life itself.

In order to open up this wider understanding of Being, the Deleuzian plane of immanence dissolves all binaries, and the categorizations that divide one from another. It locates the Divine in all matter: God and matter are not separable, any more than mind and body, interior and exterior, self and other, theory and practice, man and animal, organic and inorganic. A moment in which the subject knows itself as immanent Deleuze refers to as a haecceity. Halsey describes such moments where:

A haecceity is a moment of pure speed and intensity (an individuation) - like when a swimming body becomes-wave and is momentarily suspended in nothing but an intensity of forces and rhythms. Or like when body becomes-horizon such that it feels only the interplay between curves and surfaces and knows nothing of here and there, observer and observed. (Halsey, 2007:146)

An ethics based on immanence does not judge a being against some abstract values that exist outside being itself, but greets the other with openness: 
Somebody says or does something, you do not relate it to values. You ask yourself how is that possible? How is this possible in an internal way? In other words, you relate the thing or the statement to the mode of existence that it implies, that it envelops in itself. How must it be in order to say that? Which manner of Being does this imply? You seek the enveloped modes of existence, and not the transcendent values. It is the operation of immanence. (Deleuze, 1980)

New thought is, on this immanent plane, not the product of a subject-of-will, but emergent, lodged in events that exceed the individual and his or her will. A new idea is brought about by multiple co-implicated thoughts and affects unfolding. A new idea 'compels us to a new way of being' (Badiou, 2002: 41). Such changes might include the events of the uprising of the proletariat in Paris in 1848, or the Velvet Revolution in former Czechoslovakia in 1989. As Nietzsche said: 'The small force that it takes to launch a boat into the stream should not be confused with the force of the stream that carries it along: but this confusion appears in nearly all biographies' (2002: 297, translation modified).

It is important to note, here, that lines of flight, and the events they participate in, are not necessarily good or innocent. They are also potentially dangerous. When they take a fundamentalist turn, such that other beings may be sacrificed for what is asserted as an absolute good, they take a turn to what Badiou (2002) defines as evil.

Grenville's novel The Secret River (2005), for example, maps out the confrontation between the ex-convicts, who took up land in New South Wales in 1812, and the indigenous people who inhabited that land. The ex-convicts became no longer ordinary men, but ferocious men, madmen, engaged in mass slaughter of indigenous people, intent on their own survival at the expense of the lives of others and of their culture. Grenville shows how the ex-convicts were impelled by the emergent thought of those colonising times that made such a clash inevitablea clash already written in the thought, the lines of flight, that were emergent at that time. Each one made choices along the way. Each one had to struggle with his or her own conscience. That is true. But it is also true, at the same time, that each one was impelled by the conditions of possibility emergent in that time and that place for those people. This does not let them off the hook of critical analysis of their own choices, but it makes visible the way in which individuals are caught up in the events of their time, often unable to see where those events are taking them, or how they might think otherwise.

The poststructuralist concept of the subject, what I am calling the subject-of-thought, is where the individualised subject is under erasure, where thought and being are not separate, and where being is located in multiple subjects-including non-human subjects-the rower, the boat and the stream are co-implicated in each other. This is not a binary division between one category of subject and another. The subject-of-thought has will and the subject-of will has thought. These concepts are put forward to help us think of a difference that is, in the end, not a categorical difference; it does not provide categories into which individuals can be sorted in any one moment. It is a different way of conceptualising how we come to think and act in particular ways, and how creative evolution takes place through those actions.

Agency has generally been thought of as being in the province of the individualised subject-ofwill. Here I am suggesting that agency is linked to the opening up of new ways of being. In order to grasp the difference between these differing conceptualisations of the subject, of phenomenology's individualised subject-of-will and the poststructuralist subject-of-thought, it is important to understand that these are not equivalent, substitutable concepts, nor do they refer 
to discrete, substitutable ways of being and knowing.

The individualised subject-of-will takes its meaning inside the binary singular/plural. ' 1 ' is singular and takes its definition against 'society' which is plural. This individualised subject is understood as an active agent and the construction of it as such within Western cultures is so pervasive that it is difficult to think against the grain of it, or to imagine that agency might indeed be blocked by this constitution of subjects as individualised subjects-of-will. Poststructuralism's subject-ofthought, in marked contrast, is both singular and plural. Its plurality lies both in itself, in its own multiple singularities, and in the multiplicity of beings who are co-implicated in Being. The singular subject's specificity is ontologically real; and it observably works to accomplish a sense of itself as coherent, knowable, continuous, and predictable, as a subject-of-will (Bergson, 1998). But that orderly predictability can itself be the foundation of its own limitations and its vulnerability to institutional coercion and control, its lack of agency. I will come back to this idea in the third section of this paper.

Listening to the other, for the subject-of-will, is to judge against an imagined ideal and to find it wanting. Listening is, at the same time, used to define the borders of one's being-it establishes this is what I am not, or, this is the same as me-what I am. But lacking distance from its own listening it is also swept along by dominant discourses, becoming what those discourses want. Its own capacities for ethical thought and practice are limited by its primary attachment to the self-other binary, and to self's survival. In contrast, listening to the other, for the subject-ofthought, involves listening not just to oneself and the other, but to the boat, the river, the stars, the changing weather patterns, the waves, and their co-implication in each other. It listens to changing, emergent thought and reflects on it, is integrally co-implicated in it. It is in this capacity to listen to emergent thought that its agency lies.

The concept of co-implication is drawn from evolutionary theory:

Darwin's system of evolution specifies the ontological coimplication of animals, man, plants, rocks, and emotions. Each mode of materiality is built through its complicitous relations to others, and heredity is governed by a heterogeneous set of forces... By accentuating the structural intimacy of biology and psychology in The Expression of the Emotions in Man and Animals, Lorenz hints at one of the most underexamined aspects of Darwin's work: that evolution ... is radically heterogeneous; certainly it is biological, but it is also psychological, cultural, geological, oceanic, and meteorological. (Wilson, 2004: 69)

So how did this very different way of thinking the subject, as the subject-of-thought, emerge? Foucault took phenomenology and structuralism as his two major points of departure (Foucault, 2000: 248). He demonstrated that historical changes produce, over time, different kinds of knowledge, different relations of power, and different ways of being and thinking. Seeing history as discontinuous opens up the important possibility that the subjects of today's global capitalism can change-even more, can participate in generating thought that brings about sweeping changes. Rather than accepting the inevitability of present crises and patterns, such as neoliberalism, global economic crises, global warming, and the flight of refugees, poststructuralist theory seeks the ways in which we might break loose from those already known, habitual practices of thought that generate those crises.

For Foucault, agency lay in critique that, as he practised it in his teaching and writing, had transformative effects both for himself and for his listeners and readers. He wrote to solve problems that he saw in his everyday life. For Deleuze agency lay in radical openness to the not- 
yet-known - the lines of flight that begin with the familiar striations of the already known and then move off, at a tangent, caught up in a line of force, of flight to new ways of thinking and being.

Foucault located phenomenology's individualised subject-of-will as the single greatest impediment to thought and to agency. He described his work as using experience to wrench 'the subject from itself', to find ways to make the subject 'no longer itself' (2000: 241). He wanted to annihilate that subject of phenomenology, the subject that endlessly repeats itself, even while it understands itself as original, a unique being, sacred in its uniqueness. Foucault wanted to dissolve the phenomenological subject conceptually and ontologically, through what he called a 'project of desubjectification' (2000: 241). The new ways of thinking that he pursued opened him up to becoming someone other than himself. He was not interested in knowledge (connaissance) that makes objects intelligible, while leaving the subject, the knower, untouched. His interest was in thinking in order to know differently, and, in the process, being modified through what he came to know (savoir). His critical analyses worked toward thought that made habituated ways of being and thinking more and more difficult.

The individualised subject-of-will, then, is not, as it might have imagined, the beginning, or even the end-point of itself, but the potential sticking point, the place where thought can get stuck inside the already known. It has difficulty detaching itself from what it is, and from what it knows, since its identity is bound up with the production of that knowledge. And identity, for the subject-of-will, is all-important. There is a certain narcissism and paranoia in this subject. It positions itself and is positioned within the repeated citations of the already known, gazing upon itself as if it were original and unique, continually needing to defend itself in not matching up to its idea(I).

The conceptual shift, from the subject-of-will to the intentionality and repetition, toward receptiveness to the not-yet-known (of itself and the other), and toward emergent possibilities of thought and being where being includes all beings, human, animal and earth. In being open to the possibilities that such thought opens up, one must struggle against the limitations of the individualised subject-of-will. Such ' $t$ ] hinking is not the spontaneous effusion of a personal capacity. It is the power, won only with the greatest difficulty against oneself, of being constrained to the world's play' (Badiou, 2000: 11). It is not enough to decide to be a subject-of-thought; one has to struggle against oneself, against the normative force of language and everyday practice. It is a continuous struggle.

Deleuze and Guattari (1987) invented the concept of the 'schizo' to capture something of poststructuralism's subject-of-thought, which they contrast with the subject-of-will or 'paranoid man'. As Colebrook (2002: 5) says 'Their [concept of] 'schizo' is not a psychological type (not a schizophrenic), but a way of thinking a life not governed by any fixed norm or image of self -a self in flux and becoming, rather than a self that has submitted to law'.

Individualised subjects-of-will, then, are caught up in a paranoid play of power in which normativity is established. Those who are different, who do not live up to the right values and ideals, are abjected or cast out. More or less unable to step back from habitual ways of acting and reacting, individualised subjects struggle against each other, positioning themselves inside those repeated citations through which they have made sense of themselves, all the while understanding themselves, paradoxically, as original, and as painfully unable to live out, perfectly, their own ideal image (Davies and Harré, 1990, Davies, 2008). Foucault's philosophy seeks to break this package open: 
Thought is not what inhabits a certain conduct and gives it its meaning; rather it is what allows one to step back from this way of acting or reacting, to present it to oneself as an object of thought and to question it as to its meanings, its conditions, and its goals. Thought is freedom in relation to what one does, the motion by which one detaches oneself from it, establishes it as an object, and reflects on it as a problem. (Foucault, cited in Rabinow, 1997b: xxxv)

Or in Readings' (1996: 165) words, linking thought with listening:

Listening to Thought is not the spending of time in the production of the autonomous subject (even an oppositional one) or of an autonomous body of knowledge. Rather, to listen to Thought, think beside each other and beside ourselves, is to explore an open network of obligations that keeps the question of meaning open as a locus of debate. Doing justice to Thought, listening to our interlocutors, means trying to hear that which cannot be said but that which tries to make itself heard.

The subject-of-thought, then, is not centre stage in its own life, is not dependent on recognition within normative discourses. It is open to difference and to the other. In the face of the not-yetknown, the of thought does not leap to normative or moralistic judgements or to abjecting the other, but participates in the unfolding event, and in the evolutionary impulse to create new possibilities. It is here, I suggest, that agency lies, not in individual wilful acts, but in creative evolution.

In working against the ideas of the subject as foundational and structures as determinative, poststructuralist theory, and Deleuze in particular, place a positive value on difference.

Difference, from this perspective, is not a matter of othering through categories and categorisation but focussing on emergent possibilities within the multiplicities of being and knowing. Massey (2005: 21) describes these two approaches to difference, the categorical and the Deleuzian, as 'discrete difference' and 'continuous difference'. Discrete difference is being 'divided up, a dimension of separation', while continuous difference is 'a continuum, a multiplicity of fusion.' Discrete difference is established through categorizations and through binary thought. Continuous difference deconstructs those categories, is involved in always becoming different from itself. Deleuze wishes, in Massey's words, 'to instate the significance, indeed the philosophical primacy, of the second (continuous) form of difference over the first (the discrete) form. What is at issue' she says 'is an insistence on the genuine openness of history, of the future' (Massey, 2005: 21). And as Williams (2003: 60) points out, for Deleuze 'real difference is a matter of how things become different, how they evolve and continue to evolve beyond the boundaries of the sets they have been distributed into'. Continuous difference, or differenciation, works against the grain of those taken-for-granted, repetitive citations that maintain the moral and social order as fixed and unquestionable. Whereas the subject-of-will is locked down in that normative order, the subject-of-thought is open to continuous difference, to what can be possible when thought and being are open. The subjectof-thought is not locked down by ego and identity, by normative social orders, and by the drive toward order and safety that locks us inside the orderly striations of the already known.

In the next section of the paper I elaborate the concept of the subject-of-thought through two small moments of being in a Swedish preschool. I will extend the subject-of-thought through Nancy's (2007) concept of listening, where listening does not categorise or judge, but opens the listener, the subject-of-thought, to the not-yet-known. Nancy works both with Foucault's thinking about the struggle to efface the subject-of-will, and to expand the subject-of-thought, and Deleuze's concept of continuous difference or differenciation. 


\section{An exercise in thinking the subj-of-thought}

Methodological note. Since preschools are places where play has an emergent quality, there is, among the children, a distinct openness to what might happen next. This makes preschools interesting places in which to explore the concepts that I am trying to unfold here. The Reggio Emilia philosophy adopted in the preschool where the two moments of being that follow take place, promotes an awareness of oneself-in-relation, where children and their teachers are engaged in developing ways of knowing differently, through reflecting on their emergent ways of knowing and their means of acquiring knowledge (Davies and Gannon, 2009; Rinaldi, 2006). Reggio Emilia inspired preschools, in the words of architects Ceppi and Zini (1998: no page), provide spaces that are 'more open to the indeterminableness of experience [where the] environment is conceived not as a monologic space structured according to a formal framework and a functional order, but a place where multiple dimensions coexist-even opposing ones'. The preschool in which I made these observations in 2009 is on the edge of a small city in southern Sweden and serves a primarily working class population. It is important to note that I do not present the moments of being in the preschool as 'empirical data', but as stories that give me an analytical entry point to the philosophical questions I am working with. Through immersion in two small moments-of-being of a four year-old boy, Joshua, I open myself up, in Nancy's sense, to listening to Joshua and the other four year-olds. I see where thought takes me as I ponder on how he takes up his own emergent being in relation with others, where those others include his mother, his teacher, the other four year-olds, the wooden tiered seating, the music and the food. By focussing on the small detail of everyday life, and listening to difference where difference is a value, I explore what it might mean in practice to think of subjects as the

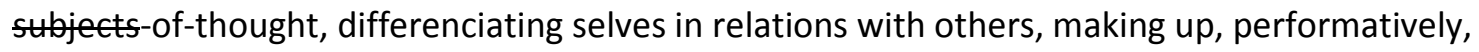
the particular place and time in which they exist as specific subjects, opening themselves up to what they might come to know in an emergent series of interactions.

It is important to reiterate here that the poststructuralist of for the subject-of-will; the subject-of-thought is not a minor variation on that originary, individualised subject of phenomenology. The subject-of-will is fundamentally conservative, working within normative discourses to establish itself as both normal and original, and as identifiably separate. One cannot choose, wilfully, to become a subj-of-thought. The of-thought is not a product of the will of the individualised subject-of-will. It is not locked down in side the striations of the already known. It is an emergent facet of being, its senses and its imagination opened to the expressive modalities of being. Its being is ontologically connected to all Being. In poststructuralist thinking, creative evolution does not spring ready made out of the brow of the individual thinker; it arises out of emergent Being, out of listening to the multiplicities of being, out of being open to becoming a place where thought happens. Thought is an act, a movement, not separable from Being, and not possessed by one individual alone. The thinking of the researcher, in such explorations in opening up thought, is not directed toward representing the 'real'. It begins with a particular case through which the researcher elaborates and explores thought. As Badiou (2000: 13) wrote in his book about Deleuze:

Certainly the starting point required by Deleuze's method is always a concrete case...It is always a question of indicating particular cases of a concept... [Y]ou place yourself where thought has already started, as close as possible to a singular case and to the movement of thought. Thinking happens 'behind your back' and you are impelled and constrained by it. ... But one starts to go wrong as soon as one imagines that the constraint exercised by concrete cases makes of Deleuze's thought a huge description or collection of the diversity characterizing the contemporary world. For one presumes then that the operation consists in thinking the case. This is not so: the case is never an object for 
thought; rather, intrinsic to the destination that, ultimately automatic, is thought's own, intrinsic to the exercising 'to the very end' of thought's power, the case is what forces thought and renders it impersonal.

The stories that follow, and the Reggio Emilia-inspired preschool setting are in this Deleuzian sense $a$ case; they form a beginning point for this paper and its unfolding of thought, and what sense we are to make of the struggle between the individualised subject-of-will and the poststructuralist preschool; I do not presume to know about them. I observe them, I reflect on them, I listen to them as a facet of being, and thought takes off from those observations, those reflections, that listening. Where thought might go is not mine alone to control or to will, but more like an act of listening to where thought might take me-might take us, since thought is by no means a solitary or singular activity.

There are 12 four year-olds assembled on the tiered wooden seats in the four year-olds' room. The teacher sits facing them. The children are putting hands up for taking turns at speaking. Joshua comes in late with his mother who gives the teacher 2 bananas in a plastic bag. The mother kneels down on the floor next to the teacher. She discusses the bananas with the teacher, explaining they are for morning tea since Joshua doesn't like the apples and pears that are provided in the preschool. The children sit quietly and listen and look. It is time for the mother to go. She kisses Joshua on the lips 3 times. He has his arms around her neck holding her tight. He lets her go, and turns towards the other children. Then he changes his mind and turns back flinging his arms around her for a fourth kiss. He finally lets her go, and his face falls into sadness. He sits down on the lower level of the seating, not close to any children in particular. His lower lip trembles and his head is bowed. The rest of the group is quiet, registering his sadness, enfolding him in quietness and sympathy, but leaving him alone, letting him gather himself together. There is no sign of rejection of this display of emotion or of his demonstration of longing for his mother.

This moment encapsulates the transition that every child makes every morning as they move from one relation to another, from being this self-in-relation to another self-in-relation. While it is often a visibly traumatic separation in the one, two and three year-olds' transitions, needing help from the teachers or the other children to manage the transition, everyone assumes here that Joshua can manage the letting go of his embeddedness in one self-in-relation and his movement to another. The self in relation to the mother, and the self in relation to the others in this room are not separate sets of relations. Joshua's mother negotiates difference for him with the teacher, while the other children listen. He is with his mother, who negotiates on his behalf, at the same time as he is a member of the listening group of children, since he too is listening. When his mother leaves, he moves to become part of the group of children, becoming one of them but apart, as he struggles with the loss of his self-in-relation to his mother. The listening of the other children, in Nancy's terms, involves their openness to him, to being penetrated by his love and his struggle in letting go even while they sit silently. To listen, Nancy says:

... is to enter that spatiality by which, at the same time, I am penetrated, for it opens up in me as well as around me, and from me as well as toward me: it opens me inside me as well as outside, and it is through such a double, quadruple, or sextuple opening that a 'self' can take place. To be listening is to be at the same time outside and inside, to be open from without and from within, hence from one to the other and from one in the other. (Nancy 2007: 14)

The children do not abject Joshua by categorising him as different, or by positioning him as needing to be turned into the same. They open themselves to the resonance of a mother who 
negotiates the possibility of bringing one's own fruit, speaking adult-to-adult on behalf of her son. They open themselves in their listening to the resonance of the kisses and the ambivalence of relinquishing the specificity of himself-in-relation to his mother. In that active listening, they create a space in which the movement goes from them as well as toward them. In this moment of being, the children, the mother and the teacher create a context in which the specific subject known as Joshua becomes possible.

The context they performatively create is in part a repetition of previous such moments. It is a clear manifestation of the Swedish commitment to parental involvement in the life of preschools, and of the Reggio Emilia philosophy of difference as a value, and of empathy for the other. It is at the same time, emergent in the present moment, a moment in which Joshua's affect in relation to his mother can be fully experienced and expressed, and in which the listening children sense and acknowledge that affect with their silent listening and their nonjudgemental gaze. The other children do not, as they might have done in another time or another place where individualism and normativity reign, mock him, or protest against the interruption to their 'lesson'. Joshua's preference for bananas and his emotional attachment to his mother, in the context of the children who listen, are performative. They establish not just that this is who Joshua is, but this is who we are (a we that includes Joshua): we are a group of people who encompass difference, and we are a group of people who know intensity of love and, equally, the expressed sorrow of parting. We each know ourselves and each other inside this moment that accomplishes who we are and who it is possible to be.

The children's knowledge of Joshua is not one that places him in a different category (the boy who comes late, the boy who doesn't like apples and pears, the boy who can't let his mother go, the boy who sits apart and shows his vulnerability), but a knowledge that it is OK to have food preferences, that mothers can be strong champions of their children, that love can be expressed openly and in public, that Joshua can both be one of them and yet separate and different. Each listening child, in Nancy's terms, is penetrated by that knowledge, each is opened to the possibility of knowing differently, to the safety of knowing differently, to expressing love openly, to taking risks. Each is open from without and from within to being different as they sit listening on the tiered wooden seats. No-one moves to shame Joshua for being different; instead he is embraced by the careful listening of the others, even by those others whose own experiences may not have included such a loving and supportive mother. Joshua's love and his sorrow open up outside them and inside them, they become selves-in-relation to Joshua and each other, each becoming the self it is possible to be in this collective act of listening, not ontologically separate, but together realising their being even while each is recognisably a named and valued individuation within that being.

Approximately 30 three to five year-olds are assembled in the big square on the tiered wooden seats. They are singing together, facing the teacher at the front who leads the singing. She demonstrates the hand movements that go with this song. Joshua and his friend are in the back row. Joshua sings with his mouth close to his friend's ear, facing his friend's ear rather than the teacher at the front. I'm not sure if he is singing the 'correct' words of the song. The mischievous expression on his face suggests not. The friend into whose ear he is singing turns around and gives him a friendly hug-more like a cuddle, and then turns back to face the front, singing the song in synchrony with the teacher and the other children and carrying out the correct hand movements. Joshua, meanwhile, is inventing his own lines of flight making up different words and hand movements while still in synchrony with the teacher and the other children. His friend starts to follow his invented movements. They are now, at the same time, part of the whole group singing together, and engaging in an improvisation of words and movement. 
The two boys are simultaneously the same and different, engaging in the same activity as the rest of the group (singing this particular song, sitting on the wooden steps together with the others) but noticeably different (they improvise words and movements). They are in-relation-tothe-group and in-relation-to-each other, apprenticed in Venn's (2002) terms to both the group and each other, listening to the group and to each other. In Nancy's terms, they are open to the music, which comes from outside them, and moves toward them. It penetrates them. It opens up in them as well as around them. Joshua' friend listens doubly to the sound of the whole group singing outside him and inside him, and he sees the movements, which become his movements too. He sings the words that he knows; the song he hears the group singing is also a song sung by him. At the same time he listens and watches Joshua's variations. He accepts those variations, demonstrating that acceptance with a hug, while still holding on to the same as the group for himself. But then he switches, taking up Joshua' variations as his own-a sextuple opening inside of which his 'self' takes place. The two boys thus listen to each other and listen to the whole group; they are open to creative difference in the other, and in themselves even as they are enfolded together with the group of children in this moment of singing. In Deleuze and Guattari's (1987) terms they stand on a familiar, safe plot of land (the song, the ritual, the place) and at the same time take off on their own line of flight (a transformative shift into the not-yetknown). In Bergson's (1998: 89) terms, they run along the rails of the already known and then, suddenly, take a divergent path into the not-yet-known: 'Life does not proceed by the association and addition of elements, but by dissociation and division'.

The two boys fold the group's song into themselves, and at the same time fold into each the innovative words and movements of the other. They also openly demonstrate love for each other and take a risk in being different. At the same time, the language of the song is Swedish, and the regular practice of singing together establishes music, and Swedish music in particular, as a significant element of being Swedish. It is a collectively learned way of enfolding oneself and being enfolded in the social fabric. The children's bodies are each archives of Swedish culture. As they sing together they accomplish their own stitching into the cultural fabric, its history, its language, its practices (Linnell, 2010). And while they do that they also accomplish a sense of themselves as different, as free to innovate within the terms of their culture, each listening to the other and taking up as their own the innovation that the other offers. Joshua enacts a facet of being made possible in this space, a space that he is, at the same time, performatively making real.

What it is possible for Joshua to be depends on what kind of subject is recognisable in this context, and on what that context affords him-how it positions him, what discourses it draws on, and what it values. He is simultaneously recognised in his specificity as a boy called Joshua, as a member of the four year-olds, as a member of the singing group, and as a loving and innovative friend who explores being different. What the preschool is depends, in turn, on how its members (which include Joshua) performatively accomplish it as a particular, recognisable place. The place exists in the moment of its production, whether that is in interactions among children, children with teachers and parents, adults with each other, interactions with the physical elements of the building and its pedagogical spaces and objects, or in the documentation of unfolding thoughts (Davies and Gannon, 2009).

Joshua's agency lies in his participation in the performative accomplishment, with others, of the openness of this place to the multiplicities of emergent, differenciating subjects accomplishing both this familiar place and new ways of being and knowing within it. Joshua does not need to wrestle with the problem of himself as an impediment to thought, in a Foucauldian sense, since he exists in a context where what he is, is understood both as specific and emergent, and where 
openness to new thought is the primary focus of the place itself.

In the next and final section of this paper I turn again to the question of what the difference is between the subject-of-will and the subject-of-thought, asking why this difference matters, and what implications it has for our thinking about agency. The cases that I draw on here are not made explicit due to the limitations of space. They are drawn from the lives of academic researchers in Australia, Sweden, New Zealand and the USA.

\section{Thinking beyond the humanist subject of phenomenology in the context of academic research} So why have poststructuralist philosophers engaged so concertedly in dismantling the foundational status of phenomenology's humanist subject and in envisaging the subject-ofthought whose emergent multiplicities are not ontologically separate from others? When Foucault reflected on what drove his commitment to the openness of history and to savoir, he linked it to his experience of growing up during WW11 (Foucault, 2000). One of the intellectuals' post-war challenges was for the human subject to evolve beyond the will to engage in, or passively permit, Nazism. Further, intellectuals felt impelled to choose between individualism and collectivism. Phenomenologists chose individualism, imagining and giving rise to an individualised, responsible subject-of-will, no longer willing (ideally at least) to engage in unquestioning obedience to the authority of an evil regime, an individual willing to accept responsibility for their individual actions. Foucault's project was more radical. He did not wish to see human action and reaction caught in any fixed place, or the installation of any new determinative order. He wanted to keep history open through engaging in the production of knowledges (savoir) that were, for both writer and reader, potentially transformative, insofar as any discourse, dominant or emergent, can be subjected to critique, a critique that makes visible the work it does on us and through us. His project assumed the desirability of creative evolution in Bergson's sense, rather than a choice between one determinative order and another.

The work that has grown out of Foucault's programme of writing, and the writing of other poststructuralist scholars, has also had a further and more recent driving force. That is the concern about the intensified individualism of neoliberal governmentality, through which the individualised subject-of-will, far from being the agent who resists oppressive regimes, becomes a machine of capital, and in the same process, used as a weapon against itself. Neoliberalism is a mode of governing individual mentalities that Foucault first observed in France and Germany in the 70s and that is now dominant in the majority of western countries.

Based on the economic theory of Hayek (1944), and re-habilitated and mobilized by both right and left governments over the last three decades, neoliberalism is a formidable regime that is extraordinarily difficult to resist. A great deal of my own thinking over the last decade has been devoted to making sense of the phenomenon of neoliberalism as it constitutes academic subjects, exposing neoliberalism to thought in order to open up the possibility of critique and transformation (see for example Bansel et al, 2008; Davies and Bansel, 2005, 2007; Davies et al, 2005; Davies and Petersen, 2005a \& b).

According to Deleuze and Guattari (1987), capitalism is schizophrenic. It needs to control its labour force in order to extract maximum productivity from it, while at the same time enhancing the production of new and creative ideas. It is constantly in flux, breaking things open to bring about new ideas and at the same time it depends on the state to be regulative in order to channel that creative energy toward the flow of capital. Neoliberalism convinces individuals they are free (that is, that their lives are directed by their own will), and at the same time it shapes them to be whatever capitalism wants. It concertedly heightens individual competition through actively increasing individual vulnerability (in part through removing responsibility for citizens' 
welfare from state to the individual, and in part through concertedly removing job security and reducing the power of unions). Each individualised subject-of-will thus feels impelled to maximise his or her own advantage within the threatening and constraining order of things. The subject-of-will, the heightened individual of neoliberalism, must become a chameleon, able to appear to be whatever a particular workplace wants, able to change in whatever way the workplace deems will maximise its productivity, ready and willing to move on to a new workplace if the old one no longer needs it or finds it valuable.At the same time the individualised subject-of-will of neoliberalism must perform itself as one who is not only original, but more original than the others with whom it competes for limited jobs and resources.

The only driving force that is legitimate for neoliberal subjects is the market, with its imperative of maximising the global flows of capital, and, implicitly, the flow of capital towards the wealthy and away from the poor. The nature of these flows is not necessarily visible or of interest to the individualised subject, who is more concerned with the fantasy of the flow of capital in its own direction. Neoliberalism is founded on a strong assertion that there is no alternative, making critique redundant. Insofar as the neoliberal individual is set loose from any remnants of conscience or collective responsibility, since capital has become the sole value, the state must serve primarily as a surveillance agency for monitoring and controlling these newly formed Hobbesian individuals, whose desire for wealth and whose fear of non-survival, drive them to perform themselves as the maximally productive, competitive subjects of neoliberalism. Turning to psychoanalysis, briefly, there is a problem with this heightened individualism embedded in a regime of fear. Individualized egos must be defended at all costs, since they are intensely aware of their potential demise. Every threat to the survival of the ego creates a wound, and the wounded ego seeks, ever more avidly, confirmation of its survivability. Neoliberal organisations exacerbate this neediness first through intensifying fear (by limiting funding and making jobs less secure), and second through presenting themselves as a major source of affirmation for the wounded ego (inviting individuals to engage in contests tightly linked to those performances the institution wishes to extract from them). The need for affirmation in turn legitimates the inordinate resources spent on surveillance and control. These contests also function to drive a desire for uniformity as each worker struggles to perform him or herself as the ideal worker, worthy of being recognized and affirmed with successive small acts of recognition. Those mechanisms of recognition are then built into the selective mechanisms within the institution. Without enough points of recognition one cannot be counted as an appropriate member of the institution. The desire for affirmation is generated first through individualized fear linked to limited resources, and second as an institutionalized imperative for individual survival.

Within neoliberal organizations difference is a threat to the organization and to the individual. The best chance for institutional and individual survival rests on everyone agreeing to be whatever it is that capital wants. Resistance is dangerous. Originality is dangerous. Critique is even more dangerous as it potentially undermines the perceived value of the affirmations that the individualized subject must want to pursue. Neoliberalism is thus a highly conservative force. It produces vulnerable workers willing both to conform and to exploit themselves for their own individualized self-survival, dividing them against each other, breaking up the co-implicative processes through which critique and transformations can be generated.

Yet capitalism relies on new ideas, on people willing to break with the already known and produce something new. Deleuze and Guattari's (1987) work is situated at the interface of capitalism's over-determined order, and the necessity for evolution, for life itself, and for ways to move beyond those controls. Their work seeks out the 'active positive lines of flight... [that] 
open up desire, ... [open up] a social field of desire...Opening up flows beneath [those] social codes that seek to channel and block them' (Deleuze, 1995: 19).

In pedagogical institutions, including universities, neoliberal managerialism has taken externally driven regulation to such extremes that the new, the creative energy that capitalism depends on, is at risk of being shut down-with only the already-known being re-circulated inside its tightly regulated relations of power and its individualized performances. One mechanism clearly working to effect this shut-down is the heightened emphasis on quantitative research and the associated trivialization of qualitative research (Davies, forthcoming). In the Australian context teaching and research ' performances' are reduced to numerical scores, and in the USA, government policy on education is to fund only quantitative and 'verifiable', empirical research. The research community is collectively positioned by government as incapable of making its own analysis of what the research questions are, and how they might best be answered. In accepting only 'empirical' findings, with an immediate benefit to business and industry, neoliberal governments suffocate and corrupt thought in the social sciences. We find ourselves locked into the intensified individualism of the subject-of-will, essentially conservative subjects, working within the striations of the already known, working within the limitations of positivism, incapable of being a place where thought might happen, where new forms of thought might emerge, where the agency necessary for creative evolution is closed down.

\section{Concluding thoughts}

How are we to open up thought? How are we to render it ethical? I have reflected here on the struggle between the individualized subject-of-will of phenomenology and the schizo subject-ofthought who might open up new thought, new lines of flight. I have suggested that the intensified subject-of-will is a formidable impediment to that thought which has the power to break with the repeated citations of the already-known. Discovering ways to listen to thoughts (one's own and others), to listen to possibilities, to resist being sidetracked by our individualized repetitions and obsessions, is a continuing struggle. I have developed the image of Joshua generating his own facets of being simultaneously inside and outside the normative order of the four year-old group and the singing group, simultaneously singular and plural, open to the emergent possibilities of doing and being in the preschool. I have played with the concepts of the individualized subject-of-will as an impediment to thought, and argued the need for poststructuralism's subject-of-thought. I have suggested that we think about the singular subjects of social science, including its singular researchers, as places where thought happens, where openness and receptiveness to difference and the other are positive values, and where the not-yet-known might emerge in lines of flight not trapped by normative regimes that block thought and the emergent possibilities of transformation.

The intensified subject-of-will is so much part of neoliberal governmentality that it may seem inevitable - not worth struggling against. Individual identity is, after all, a means of gaining recognition, of competing against others, of being seen to have value. I have tried to show here that, however desirable it may seem, intensified individualization can make us both more vulnerable and less capable of agency. The subject-of-will is constrained both by its focus on itself as primary and by the power of social organizations to manipulate it through heightening vulnerability and through foreclosing critique. The subject-of-will chooses, and in that sense has agency; but its choice is between one already known, over-determined alternative, and another. It understands its choice as coming from within itself and is blind to the ways in which that choice is driven from, or made possible by, forces outside itself. Those forces are difficult to critique since they are read as 'my own' coming from 'who I am'. The contrast, is not so focused on itself, but on thought's possibilities, on what may emerge through thought. It understands thought as emergent, as coming from both inside and outside self, and 
as always in need of critique. Agency lies in the capacity to stand back from thought, to see what it assumes and what it might accomplish, and to imagine how it might differ. It lies in the capacity to critically examine thought, and to generate new thought, using not just intellect but also imagination and the senses. It is enabled, I suggest, by a heightened capacity to listen to the other and to participate in and generate events with others that are capable of dismantling the inevitabilities of dominant, oppressive thoughts and practices.

\section{Note}

This article was presented in an earlier draft as a Keynote Address in January 2010 at the Qualitative Methods Conference: Individuality and Specificity in Qualitative Research. Brno, Czech Republic.

\section{References}

Badiou, A. (2000). Deleuze: The clamor of being. (trans L. Burchill). Minneapolis: University of Minnesota Press.

Badiou, A. (2002). Ethics: An essay on the understanding of evil. (Trans. P. Hallward) London: Verso.

Badiou, A. (2009). Theory of the Subject. London: Continuum.

Bansel, P., Davies, B., Gannon, S., Linnell, S. (2008). Technologies of audit at work on the writing subject: a discursive analysis, Studies in Higher Education. 33(6): 673-683.

Bergson, H. (1998) Creative Evolution. (Trans A. Mitchell) Mineoloa: Dover Publications. First published 1911.

Ceppi, G. and Zini, M. (eds.) (1998). Children, Spaces, Relations: Metaproject for an environment for young children, Milan: Domus Academy Research Center.

Colebrook, C. (2002). Gilles Deleuze. London: Routledge.

Davies, B. (2008). Re-thinking 'behaviour' in terms of positioning and the ethics of responsibility. In A. M. Phelan \& J. Sumsion (Eds.) Critical Readings in Teacher Education. Provoking Absences (pp. 173-186) Sense Publishers: Netherlands. (2008). (trans) K. Zabrodska, Jak znovu-promyslet 'chovani' v pojmech umistovani a etiky odpovednosti, Biograf 47, 318

Davies, B. (forthcoming). Legitimation in post-critical, post-realist times, or whether legitimation? In Paul Hart (ed.) Sage Companion to Research.

Davies, B. \& Harré, R. (1990). Positioning: The discursive production of selves. Journal for the Theory of Social Behaviour, 20(1), 43-63. Reprinted in edited form (1998) as Positioning and personhood, in R. Harré and L. van Langenhove (eds), Positioning Theory Blackwell, Oxford.32-52. Translated into Spanish and published as: (1999) Posicionamiento: la producción discursive de la identidad. Sociológica, 14(39), 215239. Reprinted in edited form (2000). In M. Wetherall, S. Taylor and S. Yates (Eds.), Discourse theory and practice: a reader, London, Sage. Reprinted in Davies, B. (2000). A Body of Writing, AltaMira Press.

Davies, B. \& Bansel, P. (2007). Governmentality and academic work: shaping the hearts and minds of academic workers. Journal of Curriculum Theorizing July 23(2): 9-26

Davies, B. \& Bansel, P. (2005). The time of their lives? Academic workers in neoliberal time(s). Health Sociology Review, 14(1): 47-58.

Davies, B., Browne, J., Gannon, S., Honan, E. \& Somerville, M. (2005). Embodied women at work in neoliberal times and places. Gender, Work and Organization, 12(4): $343-362$.

Davies, B. Browne, J. Gannon, S. Hopkins, L., McCann, H., \& Wihlborg, M. (2006). Constituting 'the subject' in poststructuralist discourse. Feminism \& Psychology, 16(1): 87-103.

Davies, B. \& Gannon, S. (2006). Doing Collective Biography. Maidenhead: Open University Press. 
Davies, B. \& Petersen, E. (2005a). Intellectual workers (un)doing neoliberal discourse. International Journal of Critical Psychology, 13, 32-54.

Davies, B. \& Petersen, E. (2005b). Neoliberal discourse in the academy: the forestalling of collective resistance. Learning and Teaching in the Social Sciences, 2(2): 77-98.

Davies B. and Gannon, S. (2009). Pedagogical Encounters. New York: Peter Lang.

Deleuze, G. (1980) Cours Vincennes, 12/21/1980, http://www.webdeleuze.com/php/texte

Deleuze, G. (1994). Difference and Repetition, New York: Columbia University Press.

Deleuze, G. (1995). Negotiations 1972-1990, New York: Columbia University Press.

Deleuze, G. and Guattari, F. (1987). A Thousand Plateaus: Capitalism and schizophrenia. London: Athlone Press.

Foucault, M. (2000). 'An interview with Michel Foucault'. In J. Faubion (Ed.). Essential Works of Foucault 1954-1984, Volume 3, Michel Foucault: Power (pp. 239-297). London: Penguin Books. Original interview conducted 1980.

Grenville, K. (2005). The Secret River. Edinburgh: Canongate.

Halsey, M. (2007) Molar ecology: what can the (full) body of an eco-tourist do?, in A. HickeyMoody and P. Malins (eds.) Deleuzian Encounters. Studies in Contemporary Social Issues, Houndmills: Palgrave Macmillan. Pp 135-150.

Hayek, F. (1944). The Road to Serfdom. London: Routledge.

Linnell, S. (2010). Art Psychotherapy and Narrative Therapy: an account of practitioner research. United Arab Emirates: Bentham Science e-books.

Massey, D. (2005). For space. London: Sage.

Nancy, J.-L. (2007). Listening. (Trans. C. Mandell). New York: Fordham University Press.

Nietzsche, F. (2002), Human All Too Human, Part 1 Assorted Opinions and Maxims (trans. H. Zimmer and P. Cohn) Cambridge University Press.

Rabinow, P. (1997a). (Ed.) Michel Foucault: Ethics, Subjectivity and Truth. New York: The New Press.

Rabinow, P. (1997b). Introduction. In P. Rabinow (Ed.) Michel Foucault. Ethics Subjectivity and Truth. The New Press: New York, xi-xlii.

Readings, B. (1996) The University in Ruins. Cambridge MA: Harvard University Press

Rinaldi, C. (2006). In Dialogue with Reggio Emilia: Listening, Researching and Learning. London: Routledge.

Venn, C. (2002). Refiguring subjectivity after modernity. In V. Walkerdine (Ed.) Challenging Subjects: Critical Psychology for a New Millenium. Houndsmills, UK: Palgrave. Pp 51-71.

Williams, J. (2003). Gilles Deleuze's 'Difference and repetition': a critical introduction and guide, Edinburgh: Edinburgh University Press.

Wilson, E. A. (2004). Psychosomatic: Feminism and the neurological body. Durham: Duke University Press. 